\title{
Çölyak hastalarında serum homosistein düzeylerinin değerlendirilmesi
}

\author{
Evaluation of serum homocysteine levels in children with celiac disease
}

\author{
Atakan Comba, Fatma Demirbaş, Esra Eren, Gönül Çaltepe, Hüseyin Kayadibi,
}

Ayhan Gazi Kalaycı

\section{Özet}

Amaç:Çölyak hastalığı, genetik yatkın bireylerde diyetle gluten içeren tahılların tüketilmesi sonucu oluşan otoimmün, kronik inflamatuar bir hastalıktır. Çölyak hastalığında, malabsorbsiyona bağlı folat ve vitamin B12 eksikliği sık gelişir. Bu vitaminlerin eksiklikleri hiperhomosisteinemiye neden olabilir. Hiperhomosisteineminin venöz tromboemboli, ateroskleroz, inme gibi vasküler hastalıklarla ilişkisi iyi bilinmektedir. Çalışmanın amacı çölyak hastalığı olan çocuklarda serum homosistein düzeylerini incelemek ve glutensiz diyetin bunun üzerindeki etkisini araştırmaktır.

Gereç ve yöntem:Çalışma, Temmuz 2013-Kasım 2016 tarihleri arasında yapıldı. Çölyak hastaları yeni tanılı ve takipli çölyak hastaları olarak iki gruba ayrıldı. Takipli çölyak hastaları en az bir yıldır izlemde olan hastalardan seçildi ve glutensiz diyet uyumuna göre iki gruba ayrıldı. Hastaların sosyodemografik, antropometrik özellikleri ve laboratuvar değerleri kaydedildi. Serum homosistein düzeyi ELISA yöntemi ile çalışıldı.

Bulgular:Çalışmaya 106'sı (\%63.9) kız olmak üzere toplam 166 çocuk alındı. Yaş ortalamaları 9.6 \pm 4.9 yıldı Çocukların 50'si (\%30.1) yeni tanı çölyak, 57'si (\%34.3) takipli çölyak ve 59'u (\%35.5) sağlıklı kontroldü. Çölyak hastalarının 69'u (\%64.5) diyetine tam uyuyordu.

Çölyak hastalarının folat düzeyi $(8.9 \pm 4.1 \mathrm{mg} / \mathrm{dL})$ sağlıklı çocuklara göre $(10.3 \pm 3.2 \mathrm{mg} / \mathrm{dL})$ anlamlı olarak düşük $(p=0.042)$, homosistein düzeyi de $8.9(2.8-49.5) \mathrm{nmol} / \mathrm{mL}$; sağlıklı gruba göre $8.2(4.7-25.8) \mathrm{nmol} / \mathrm{mL}$ anlamlı olarak yüksekti $(p=0.032)$.

Sonuç:Çalışmamızda, çölyak hastalarında serum folat düzeyi daha düşük homosistein düzeyi de daha yüksek saptandı. Bu durum yeni tanı çölyak hastalarında en belirgindi. Çölyak hastalarında folat eksikliğine bağlı görülen hiperhomosisteinemi ciddi komplikasyonlara neden olabilir. Bu nedenle hastalar glutensiz diyete ilaveten folat, B12 gibi mikrobesin öğelerinin eksikliği yönünden de düzenli olarak taranmalı ve eksiklik durumunda mutlaka hiperhomosisteinemi varlığı araştırılmalıdır.

Anahtar sözcükler: Çocuk, çölyak hastalığı, folat, homosistein

Comba A, Demirbaş F, Eren E, Çaltepe G, Kayadibi H, Kalaycı AG. Çölyak hastalarında serum homosistein düzeylerinin değerlendirilmesi. Pam Tıp Derg 2018;11(3);215-222.

\footnotetext{
Abstract

Purpose: Celiac disease is an autoimmune, chronic inflammatory disease which occurs as a result of consuming gluten containing grains in genetically predisposed individuals. In celiac disease, malabsorption dependent folate and vitamin B12 deficiencies develop frequently. These deficiencies can cause hyperhomocysteinaemia. Hyperhomocysteinaemia is known to be associated with vascular diseases such as venous thromboembolism, atherosclerosis and stroke. The purpose of the study is to analyze serum homocysteine levels in children with celiac disease and to examine the effect of this on gluten-free diet.

Materials and methods: The study was conducted between July 2013 and November 2016. Celiac patients were grouped as newly diagnosed and follow-up. Follow up children with celiac disease were chosen from at least one-year disease follow-up and grouped into two according to their compliance to gluten-free diet. The patients' sociodemographic and anthropometric features and laboratory values were recorded. Serum homocysteine level was determined with ELISA method.

Results:A total of 166 children, $106(63.9 \%)$ of whom were girls, were included in the study. The average age of the patients were 9,6 $\pm 4,9$. Fifty $(30.1 \%)$ children were newly diagnosed celiac patients, $57(34.3 \%)$

Atakan Comba, Dr.Öğr.Üyesi, Hitit Üniversitesi Tıp Fakültesi, Çocuk Sağlığı ve Hastalıkları Anabilim Dalı, ÇORUM, e-posta: adcomba gmail. com (orcid.org/0000-0002-8576-9550) (Sorumlu yazar)

Fatma Demirbaş, Uzm.Dr. Ondokuz Mayıs Üniversitesdi Tıp Fakültesi, Çocuk Gastroenteroloji Hepatoloji Beslenme Anabilim Dalı, SAMSUN, e-posta: fatmademirbas81@hotmail.com (orcid.org/0000-0003-1788-2559)

Esra Eren, Uzm.Dr. Ondokuz Mayıs Üniversitesdi Tıp Fakültesi, Çocuk Gastroenteroloji Hepatoloji Beslenme Anabilim Dalı, SAMSUN, e-posta: esraeah@hotmail.com (orcid.org/0000-0001-7506-4672)

Gönül Çaltepe, Prof.Dr. Ondokuz Mayıs Üniversitesdi Tıp Fakültesi, Çocuk Gastroenteroloji Hepatoloji Beslenme Anabilim Dalı, SAMSUN, e-posta: caltepeg@gmail.com (orcid.org/0000-0001-8525-6352)

Hüseyin Kayadibi, Doç.Dr. Hitit Üniversitesi Tıp Fakültesi Tıbbi Biyokimya Anabilim Dalı, ÇORUM, e-posta: mdkayadibi@yahoo.com (orcid. org/0000-0002-3922-4517)

Ayhan Gazi Kalaycı, Prof.Dr. Ondokuz Mayıs Üniversitesdi Tıp Fakültesi, Çocuk Gastroenteroloji Hepatoloji Beslenme Anabilim Dalı, SAMSUN e-posta: ayhangk@omu.edu.tr (http://orcid.org/0000-0003-2104-6801)
} 
were follow-up celiac patients and $59(35.5 \%)$ were healthy controls. Folate level of celiac patients $(8.9 \pm 4.1$ $\mathrm{mg} / \mathrm{dL}$ ) was found to be significantly lower and homocysteine level $(8.9(2.8-49.5) \mathrm{nmol} / \mathrm{mL})$ was found to be significantly higher when compared with healthy children $(10.3 \pm 3.2 \mathrm{mg} / \mathrm{dL}, 8.2(4.7-25.8) \mathrm{nmol} / \mathrm{mL}$, respectively) $(p=0.042=0.032)$.

Conclusion:In our study, celiac patients were found to have lower folate level and higher homocysteine level. This situation was the distinct detail in newly diagnosed patients. In celiac patients, hyperhomocysteinaemia as a result of folate deficiency can cause serious complications. Thus, the celiac patients should be screened regularly in terms of the deficiency of micro food elements and in case of deficiency, hyperhomocysteinaemia presence should be researched.

Key Words: Child, celiac disease, folate, homocysteine

Comba A, Demirbaş F, Eren E, Çaltepe G, Kayadibi H, Kalaycı AG. Evaluation of serum homocysteine levels in children with celiac disease. Pam Med J 2018;11(3):215-222.

\section{Giriş}

Çölyak hastalığı (ÇH), genetik yatkın bireylerde diyetle gluten içeren tahılların tüketilmesi sonucu oluşan otoimmün, kronik inflamatuar ve sistemik bir hastalıktır [1]. Dünya genelinde çocuklarda ÇH prevalansı yaklaşık \%0,5-1 arasındadır [2]. Ülkemizde yapılan çok merkezli bir çalışmada ÇH prevalansı \%0,47 olarak bulunmuştur [3].

Hastalık tipik, atipik ve sessiz formlarda görülebilir. Hastalık tipine göre klinik bulgular değişir [4]. Tipik ÇH klasik olarak 6-24 ay arasında diyete gluten girdikten sonra başlayan kronik ishal, karın şişliği, kilo kaybı gibi bulgularla seyreden bir hastalıktır [5]. Bu bulgular dışında hastalık gastrointestinal sistem dışı çok geniş bir spektrumla da karşımıza gelebilir. Günümüzde hastaların yaklaşık \%50'si gastrointestinal sistem dışı semptomlarla tanı almaktadır, bu nedenle ÇH günümüzde sistemik bir hastalık olarak kabul edilmektedir $[4,5]$.

Çölyak hastalığında ince bağırsak hasarı nedeniyle malabsorpsiyon gelişir ve bu durum demir, kalsiyum, folat ve B12 gibi mikro besin eksikliklerine yol açar [6]. Bu eksiklikler, hastalarda çeşitli fizyolojik süreçlerde değişikliğe neden olabilir. Çölyak hastalığında bağırsaklarda meydana gelen inflamasyon ve/veya kronik ishal nedeniyle azalmış folat konjugaz aktivitesi ve enterohepatik sirkülasyonun bozulması folat kaybını artırır [7]. Primer emilim yeri ileum olan vitamin $\mathrm{B}_{12}$, proksimal ince bağırsakta intrensek faktörle kompleks oluşturduğu için ÇH'de eksikliğine diğer mikrobesinlere göre daha az rastlanılır [8].

Homosistein, metionin sentez yolunun bir ara metaboliti olan sülfürlü bir aminoasittir [9]. Folat ve riboflavin, vitamin $B_{6}$ ve vitamin $B_{12}$, homosistein metabolizmasında görevli enzimler için substrat ve temel kofaktörlerdir [10, 11]. Bu vitaminlerin yetersizliği sıklıkla serum homosistein yüksekliğine (hiperhomosisteinemi) neden olur $[12,13]$. Serum homosistein düzeyi ayrıca yaş, cinsiyet, beslenme faktörleri, sigara, metionin içeren hayvansal proteinlerin fazla alımı, genetik nedenler ve kortikosteroid, siklosporin gibi ilaçlardan da etkilenmektedir [14].

Hiperhomosisteineminin vasküler endotel hasarı, venöz tromboemboli, ateroskleroz gelişimi, tekrarlayan düşükler ve osteoporoz ile ilişkili olduğu bilinmektedir [15]. Birçok çalışma, orta derecede hiperhomosisteineminin tekrarlayan venöz tromboembolizm ve aterotrombotik vasküler hastalık için bağımsız bir risk faktörü olduğuna işaret etmektedir [1214].

Çölyak hastalığında, malabsorbsiyona bağlı gelişen vitamin eksikliklerinde hiperhomosisteinemi görülebilir ve bu duruma bağlı tromboemboli ve ateroskleroz vakaları bildirilmiştir [16, 17]. Bu nedenle Amerikan Kalp Birliği, malabsorpsiyon sendromlu hastalarda hiperhomosisteinemi için tarama yapılmasını önermektedir [18]. Çölyak hastalarında glutensiz diyet (GD) ile serum homosistein düzeyi genellikle düzelmektedir $[6,16]$. Ancak bazı çalışmalarda sıkı GD'ye rağmen hiperhomosisteineminin devam ettiği gösterilmiştir [15].

Çalışmamızın amacı, ÇH olan çocuklarda, serum homosistein düzeylerini belirlemek ve sağlıklı çocuklarla karşılaştırmaktır. Ayrıca, çölyak hastalarında sosyodemografik veriler ile tedavi uyumunun serum homosistein düzeyi üzerindeki etkisini araştırmak amaçlanmıştır. 


\section{Gereç ve Yöntem}

Çalışma, Ondokuz Mayıs Üniversitesi Tıp Fakültesi ve Hitit Üniversitesi Tıp Fakültesi Çocuk Gastroenteroloji Hepatoloji ve Beslenme Bölümlerinde $\quad 01.07 .2013$ ve 15.11.2016 tarihleri arasında yapıldı. Çalışmaya çölyak hastaları ve sağlıklı çocuklar alındı. Çölyak hastalığı tanısı Avrupa Çocuk Gastroenteroloji Hepatoloji ve Beslenme Derneği (ESPGHAN) 2012 kriterlerine göre kondu [19]. İnce bağırsak biyopsilerinin histopatoloji değerlendirmesi modifiye Marsh (Oberhuber) sınıflaması ile yapıldı [20]. Çalışmaya alınan hastalar üç gruba ayrıldı: Yeni tanı çölyak hastaları: Çalışma tarihleri arasında başvuran ve ÇH tanısı alan hastalar bu gruba dahil edildi. Takipli çölyak hastaları: Çölyak hastalığı tanısı ile en az bir yıldır izlenen hastalar bu gruba alındı. Glutensiz diyet sonrası bakılan doku transglutaminaz IgA ve/veya endomisyal antikor sonucu negatif olan hastalar: "GD"ye tam uyumlu"; pozitif olanlar ise "GD"ye uyumsuz" olarak sınıflandırıldı."

Hastaların; sosyodemografik verileri, antropometrik ölçümleri, hematolojik ve biyokimyasal parametreleri, antiendomisyum ve doku transglutaminaz antikorları, endoskopi ve ince bağırsak patoloji bulguları kaydedildi.

Kontrol grubu: Çalışma tarihleri arasında polikliniğe başvuran, bilinen bir kronik hastalığı olmayan 59 hasta kontrol grubu olarak seçildi. Kontrol grubundaki hastaların da sosyodemografik verileri ve antropometrik ölçümleri kaydedildi.

Biyokimyasal Test Analizleri: Hastalardan 8-12 saat açlıktan sonra $\mathrm{K}_{2}$ EDTA içeren tüplere alınan kan örneklerinden aynı gün içinde tam kan sayımı analizi yapıldı. Ayrıca, yaklaşık $4 \mathrm{~mL}$ kadar kan pıhtı aktivatörlü tüplere alındı. Alınan kan örnekleri 3000 rpm'de 5 dakika santrifüj edildikten sonra serumları ayrıldı. Serum demiri, demir bağlama kapasitesi, satürasyon, ferritin, folat, vitamin B12, AST, ALT, kalsiyum, albümin testleri aynı gün çalışıldı. Homosistein ölçümü için ayrılan serum ise çalışma zamanına kadar $-80^{\circ} \mathrm{C}$ de saklandı. Homosistein ölçümü için serum örnekleri oda ısısında çözündürüldükten sonra, ELISA yöntemi ile üretici firmanın kit prospektüsüne uygun olarak çalışıldı (Axisshield Birleşik Krallık, katalog no: FHYC100). Çalışma için Ondokuz Mayıs Üniversitesi Klinik
Araştırmalar Etik Kurul'undan çalışma izni ve onayı alındı (OMÜ KAEK no: 2017/362).

\section{İstatistiksel Analiz}

Normal dağılım gösteren veriler ortalama \pm standart deviasyon; normal dağılım göstermeyen veriler ortanca (en küçük - en büyük) olarak verildi. Normal dağılım gösteren bağımsız ikili gruplar $\mathrm{t}$ testi ile ikiden fazla grup değişkeni olanlar one-way ANOVA ile karşılaştırıldı. Íkili karşılaştırmalarda Tukey testi kullanıldı. Normal dağılış göstermeyen verilerde ikili gruplar Mann-Whitney $U$ testi ile, ikiden fazla değişkenli gruplar Kruskal Wallis testi ile karşılaştırıldı ve bonfferoni düzeltmesi yapıldı. Nitel veriler için yüzdeler karşılaştırılırken pearson ki-kare testi ve z testi yapıldı. Sürekli değişkenler arasındaki ilişkiler parametrik olmayan Spearman's korelasyon katsayısı ile araştırıldı. Spearman korelasyon katsayısına göre ilişki yorumlamalarında referans aralıkları $0.00<r<0.25$ : çok zayıf; $0.26<r<0.49$ : zayıf; $0.50<r<0.69$ : orta; $0.70<r<0.89$ : yüksek; $0.90<r<1.00$ : çok yüksek olarak kabul edildi. p'nin 0.05'ten küçük olması anlamlı kabul edildi.

\section{Bulgular}

Çalışmaya 106'sı (\%63.9) kız olmak üzere toplam 166 çocuk alındı. Yaşları ortancası 10 (1-17) yıldı. Çocukların 50'si (\%30.1) yeni tanı çölyak, 57'si (\%34.3) takipli çölyak ve 59'u (\%35.5) da sağlıklı kontrolidi. Çölyak hastalarının 69'u (\%64.5) atipik çölyak hastasıydı. Takipli çölyak hastalarının takip süresi 47 (12-182) aydı ve 33'ü (\%58) diyetine tam uyuyordu (Tablo 1). Çölyak hastalarının duodenum biyopsilerinin 35’i (\%32.7) Marsh 3a, 40’ı (\%37.3) Marsh 3b, 32'si (\%30) Marsh 3c' idi.

Yeni tanı çölyak hastalarının hemoglobin, hematokrit, MCV düzeyleri sağlıklı grup ve takipli çölyak hastalarına göre anlamlı olarak düşüktü (sırasıyla $p<0.001, p<0.001, p<0.001$ ). Ferritin ve vitamin B12 düzeyleri arasında gruplar arasında fark yoktu $(p=0.819, p=0.929$, sırasıyla). Yeni tanı çölyak hastalarının albümin düzeyi, takipli çölyak hastalarına göre anlamlı olarak düşüktü ( $p<0.001$, Tablo 2).

Çölyak hastalarının folat düzeyi $(8.9 \pm 4,1$ $\mathrm{mg} / \mathrm{dl})$ sağlıklı çocuklara göre $(10.3 \pm 3.2 \mathrm{mg} /$ dl) anlamlı olarak düşüktü $(p=0.042)$. Yeni tanı 
çölyak hastalarında ve GD’ye uymayan çölyak hastalarında folat düşüklüğü sıklığı, GD'ye tam uyumlu ve sağlıklı gruba göre anlamlı olarak yüksekti (sırasıyla, \%23.9, \%20, \%3.6, \%\%2.2) $(p=0.006)$.

Çölyak hastalarının homosistein düzeyi 8.9 (2.9-48.5) nmol/mL, sağlıklı grubun homosistein düzeyinden $8.2(4.7-25.8) \quad \mathrm{nmol} / \mathrm{mL}$ anlamlı olarak yüksekti $(p=0.032)$.

Yeni tanı çölyak hastalarının homosistein düzeyi 9.3 (2.8-49.5) nmol/mL; sağlıklı grubun homosistein düzeyinden 8.2 (4.7-25.8) anlamlı olarak yüksekti $(p=0.018)$. Takipli çölyak hastaları 8.7 (4.3-41.7) nmol/mL ile sağlıklı grup arasında bir fark saptanmadı (sırasıyla, $p=0.197, p=0.544)$. Takipli çölyak hastalarından GD'ye tam uyanların homosistein düzeyi 8.4 (4.2-41.7) nmol/mL ile GD'ye uyumsuz hastalar 9,5 (4.3-37.4) nmol/mL arasında istatistiksel olarak bir fark saptanmadı $(p=0.309$, Tablo 3 , Şekil 1).

Homosistein düzeyi ile çocukların cinsiyeti, yaşı, boy, ağırık, laboratuar değerleri arasında bir korelasyon saptanmadı. Çölyak hastalarının takip süresi ve çölyak tipi ile serum homosistein düzeyi arasında da bir ilişki saptanmadı.

\section{Tartışma}

Çölyak hastalığı, ince bağırsaklarda kronik inflamasyonla giden genetik otoimmün bir hastalıktır. Bu inflamasyon sonucu oluşan mikrobesin eksiklikleri, anemi, folat, vitamin B12 eksikliği ve osteoporoz gibi komplikasyonlara neden olur [7, 8]. Shephard ve ark. [21],
Kemppainen ve ark. [22] ile Valante ve ark. [23] çalışmalarında çölyak hastalarında folat düzeyini sağlıklı bireylere göre düşük olarak bildirmektedirler. Çölyak hastalarında folat eksikliği oranını Wierdsma ve ark. [24] \%20, Saibeni ve ark [16] \%43.5 olarak bildirmiştirler. Ülkemizde yapılan çalışmalarda da çölyak hastalarında \%15.7-31.3 oranlarında folat eksikliği saptanmıştır [25-27]. Bizim çalışmamızda da benzer olarak çölyak hastalarının \%17'sinde folat eksikliği saptandı. Bu oran yeni tanı çölyak hastalarında ve GD'ye uyumsuz çölyak hastalarında GD uyumlu olanlara ve sağlıklı gruba göre anlamlı olarak yüksekti.

Hiperhomosisteinemi, homosistein metabolizmasında görevli enzimlerin genetik eksikliğinden veya bazı ilaçlar, sigara kullanımı ve kronik böbrek yetmezliği gibi durumlardan kaynaklanabilir [28]. Ancak, yapılan çalışmalarda hiperhomosisteineminin 2/3'ünün folat, B6 ve vitamin B12 eksikliklerinden de kaynaklanabileceği rapor edilmiştir [13, 29]. Çölyak hastalarında benzer olarak serum folat düzeyi, homosistein düzeyinin bağımsız belirleyicilerindendir [30]. Bu nedenle malabsorbsiyon durumlarında bu vitamin eksikliklerine sekonder hiperhomosisteinemi sıklıkla eşlik edebilir [18].

Çölyak hastalığı, çocuklarda malabsorbsiyon sendromlarının başında gelmektedir [4, 6]. Yapılan çok sayıda çalışmada, çölyak hastalarında homosistein düzeyleri genel popülasyona kıyasla yüksek saptanmıştır [6, 16, 17]. Bu durum folat ve vitamin B12 eksiklikleriyle

Tablo 1. Çalışma grubunun genel özellikleri

\begin{tabular}{|c|c|c|c|c|c|c|}
\hline & \multirow[t]{2}{*}{ n (\%) } & \multicolumn{2}{|c|}{ Cinsiyet } & \multirow{2}{*}{$\begin{array}{l}\text { Yaş } \\
\text { (yıl) }\end{array}$} & \multicolumn{2}{|c|}{ Çölyak tipi } \\
\hline & & $\mathbf{K} \mathbf{z}$ & Erkek & & Tipik & Atipik \\
\hline Yeni tanı çölyak & $50(\% 30.1)$ & $39(\% 78)$ & $11(\% 22)$ & $\begin{array}{c}8.5 \\
(1-17)\end{array}$ & $10(\% 20)$ & $40(\% 80)$ \\
\hline \multicolumn{7}{|l|}{ Takipli çölyak } \\
\hline & & & & 10 & & \\
\hline Diyetine tam uyan & $33(\% 19.9)$ & $21(\% 63.6)$ & $12(\% 36.4)$ & $(2-17)$ & $14(\% 42.4)$ & $19(\% 52.6)$ \\
\hline Diyetine uymayan & $24(\% 14.5)$ & $14(\% 53.5)$ & $10(\% 41.7)$ & $\begin{array}{c}12,5 \\
(5-17)\end{array}$ & $14(\% 58.3)$ & $10(\% 41.7)$ \\
\hline Sağlıklı kontrol & $59(\% 35.5)$ & $32(\% 54.2)$ & $27(\% 45.8)$ & $\begin{array}{c}10 \\
(1-17)\end{array}$ & & \\
\hline Toplam & $166(\% 100)$ & 106 & 60 & & $38(\% 35.5)$ & 69 (\%64.5) \\
\hline
\end{tabular}


Tablo 2. Gruplara göre laboratuvar değerlerinin karşılaştırılması

\begin{tabular}{|c|c|c|c|c|c|}
\hline & Yeni tanı çölyak & $\begin{array}{c}\text { Diyetine tam } \\
\text { uyan }\end{array}$ & $\begin{array}{l}\text { Diyetine } \\
\text { uymayan }\end{array}$ & Sağlıklı Grup & $\mathbf{p}$ \\
\hline $\begin{array}{l}\text { Hemoglobin } \\
\text { (gr/dL) }\end{array}$ & $11.1 \pm 2^{\mathrm{a}}$ & $13.1 \pm 1.5^{b}$ & $12.8 \pm 1.4^{\mathrm{b}}$ & $12.6 \pm 1.1^{b}$ & $<0.001$ \\
\hline Hematokrit (\%) & $35(16-43)^{\mathrm{a}}$ & $38(32-52)^{b}$ & $39(29-45)^{b}$ & $38(25-45)^{\mathrm{b}}$ & $<0.001$ \\
\hline MCV (fL) & $75.6 \pm 5.6^{a}$ & $85 \pm 5.3^{b}$ & $82 \pm 5.7^{b}$ & $81.5 \pm 5.7^{b}$ & $<0.001$ \\
\hline $\begin{array}{c}\text { Beyaz küre } \\
\left(10^{3} / \mathrm{mm}^{3}\right)\end{array}$ & $7.4(3.5-21)^{a}$ & $8(3.6-14)^{a}$ & $6.1(3.6-11)^{b}$ & $7.7(4.4-13)^{a}$ & 0.028 \\
\hline $\begin{array}{l}\text { Trombosit } \\
\left(10^{3} / \mathrm{mm}^{3}\right)\end{array}$ & $\begin{array}{c}357 \\
(197-1068)\end{array}$ & $\begin{array}{c}345 \\
(174-498)\end{array}$ & $\begin{array}{c}311 \\
(210-487)\end{array}$ & $\begin{array}{c}313 \\
(173-269)\end{array}$ & 0,227 \\
\hline $\begin{array}{l}\text { Serum Demiri } \\
(\mu \mathrm{g} / \mathrm{dL})\end{array}$ & $\begin{array}{c}35^{\mathrm{a}} \\
(4-487)\end{array}$ & $\begin{array}{c}86^{b} \\
(13-182)\end{array}$ & $\begin{array}{c}76^{\mathrm{b}} \\
(17-182)\end{array}$ & $\begin{array}{c}56^{\mathrm{b}} \\
(18-150)\end{array}$ & 0.027 \\
\hline $\begin{array}{l}\text { TDBK* } \\
\text { ( } \mu \mathrm{g} / \mathrm{dL})\end{array}$ & $387 \pm 94$ & $377 \pm 77$ & $410 \pm 48$ & $378 \pm 46$ & 0.366 \\
\hline Satürasyon (\%) & $8(1-95)^{a}$ & $26(2-238)^{b}$ & $21(3-48)^{\mathrm{ab}}$ & $18(1-60)^{\mathrm{ab}}$ & 0.024 \\
\hline Ferritin (ng/mL) & $11(2-1201)$ & $29(4-86)$ & $16(4-48)$ & $24(10-219)$ & 0.819 \\
\hline B12 (pg/mL) & $\begin{array}{c}352 \\
(107-992)\end{array}$ & $\begin{array}{c}411 \\
(236-751)\end{array}$ & $\begin{array}{c}303 \\
(144-2000)\end{array}$ & $\begin{array}{c}305 \\
(64-4000)\end{array}$ & 0.929 \\
\hline Folat (ng/mL) & $8 \pm 4.2^{\mathrm{a}}$ & $10.9 \pm 3.6^{b}$ & $8.3 \pm 3.7^{\mathrm{ab}}$ & $10 \pm 3.2^{b}$ & 0.002 \\
\hline AST (U/L) & $30.9 \pm 11^{a}$ & $23.6 \pm 4^{b}$ & $24.7 \pm 6^{\mathrm{ab}}$ & $28.1 \pm 10^{\mathrm{ab}}$ & 0.008 \\
\hline ALT (U/L) & $16(6-58)$ & $17(5-49)$ & $19(8-32)$ & $15(10-26)$ & 0.621 \\
\hline $\mathrm{Ca}^{++}(\mathrm{mg} / \mathrm{dL})$ & $9.3 \pm 0.7^{a}$ & $9.8 \pm 0.2^{\mathrm{ab}}$ & $10.1 \pm 0.3^{b}$ & $9.9 \pm 0.9^{\mathrm{ab}}$ & 0.004 \\
\hline Albumin (g/dL) & $4.2(1.9-4.9)^{a}$ & $4.6(3.8-5.1)^{b}$ & $3.9(4.6-5)^{\mathrm{a}}$ & $4.0(3.8-4.9)^{a}$ & $<0.001$ \\
\hline
\end{tabular}

*total demir bağlama kapasitesi; a,b,c harfleri gruplar arasındaki istatistiksel farkları sembolize etmekte olup, bu üç harften ortak olanları içermeyen satırlar arasında istatistiksel fark vardır, gruplar arası $p$ değeri son satırda verilmiştir.

Tablo 3. Gruplara göre homosistein düzeylerinin karşılaştırılması

\begin{tabular}{ccc}
\hline & Serum homosistein düzeyi (nmol/mL) & $p$ \\
\hline Çölyak hastaları (tümü) & $8.9(2.8-49.5)$ & $\mathbf{0 . 0 3 2}$ \\
Sağlıklı Grup & $8.2(4.7-25.8)$ & 0.197 \\
Yeni tanı çölyak hastaları & $9.3(2.8-49.5)$ & 0.309 \\
Takipli çölyak hastaları & $8.7(4.3-41.7)$ & $8.4(4.2-41.7)$ \\
Diyetine tam uyan hastaları & $9.5(4.3-37.4)$ &
\end{tabular}



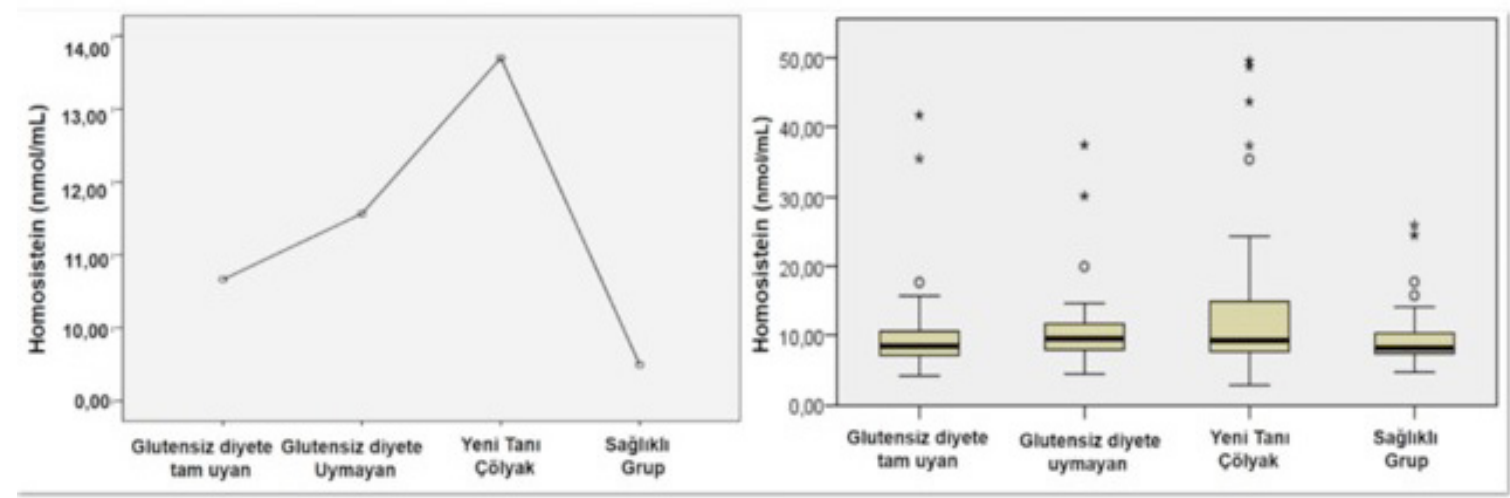

Şekil 1. Gruplara göre homosistein düzeyleri

ilişkidir. Çalışmamızda da benzer olarak çölyak hastaların homosistein düzeyi sağlıklı kontrol grubuna göre anlamlı olarak yüksek bulundu.

Homosistein, primer olarak aterojenik ve protrombotik özelliğe sahiptir. Homosistein, intima kalınlığına neden olan vasküler hasarı indükler, elastik laminayı harap eder, trombosit aktivasyonu ve trombüs formasyonu oluşumunu aktive eder [29, 31]. Böylece arteriyel hastalıklar ve venookluziv hastalıkların gelişme riskini artıır. Çeşitli çalışmalarda, ılımlı homosistein yüksekliğinin aterotrombotik damar hastalıkları için bağımsız bir risk faktörü olduğu gösterilmiştir [30]. Çölyak hastalarında hiperhomosisteinemiye bağlı hepatik ven trombozu, derin ven trombozu, stroke ve pulmoner emboli olguları bildirilmiştir [3235]. Çalışmamızda olguların hiçbirinde klinik bulgu veren vasküler hastalık yoktu. Ancak, vasküler hastalıkların kronik ve progresif olması nedeniyle ilerleyen yaşlarda bulgu verdiği de bilinmektedir [36].

Saibeni ve ark. [16] GD ile beslenen hastalarda 1 yıllık tedavi sonrasında serum homosistein düzeyinde azalma saptarken, De Marchi ve ark. [37] 6-8 aylık tedaviden sonra bu etkiyi gözlemlemediğini belirtmiştir. Hadithi ve ark. [30] çölyak hastalarında vitamin takviyesinin, homosistein düzeyleri üzerine etkisini araştırmış; vitamin takviyesi alan grupta, almayan gruba göre plazma homosistein düzeylerini daha düşük bulmuştur.

Çalışmamızda GD'ye tam uyumlu çocuklarda hem folat hem de homosistein düzeyleri normal saptandı. GD'ye uyumsuz çölyak hastalarında ise homosistein düzeyi normale gelmişti, ancak folat eksikliği GD'ye tam uyanlara göre daha sıktı. Tüm çölyak hastalarına folat tedavisi verilmesine rağmen GD'ye uymayan hastalarda folat düşüklüğünün devam etmesi, uzun süreçte hiperhomosisteinemi gelişmesine neden olabilir ve bu durum vasküler hastalıkların gelişimi için büyük risk oluşturmaktadır [6, 16, 23].

Çalışmanın kısıtlııkları, çalışmaya serum homosistein düzeyini etkileyebileceği için bilinen kronik hastalığı olanlar alınmadı, ancak homosistein yüksekliği yapabilecek ailesel ve genetik faktörler dışlanamadı.

Sonuç olarak, çalışmamızda çölyak hastalarında serum folat düzeyi daha düşük ve homosistein düzeyi ise yüksek saptandı. Takipte tüm hastalarda homosistein düzeyi normale gelmişti. Ancak, GD'ye uyumsuzlarda folat eksikliği devam ediyordu. Çölyak hastalarında folat eksikliği ve hiperhomosisteinemi uzun dönemde önemli komplikasyonlara neden olabilir. Bu nedenle yeni tanı çölyak hastaları folat eksikliği ve hiperhomosisteinemi yönünden taranmalı, takipli hastalar GD uyumu açısından yakın denetlenmeli ve GD uyumsuz hastalar folat eksikliği yönünden değerlendirilmeli ve eksikliği durumunda tedavisi düzenlenmelidir.

Çıkar ilişkisi: Yazarlar herhangi bir çıkar ilişkileri bulunmadığını beyan eder.

\section{Kaynaklar}

1. Fasano A. Clinical presentation of celiac disease in the pediatric population. Gastroenterology 2005;128:S6873.

2. Mustalahti K, Catassi C, Reunanen A, et al. The prevalence of celiac disease in Europe: results of a centralized, international mass screening project. Ann Med 2010;42:587-595.

3. Dalgic B, Sari S, Basturk B, et al. Prevalence of celiac disease in healthy Turkish school children. Am J Gastroenterol 2011;106:1512-1517. 
4. Lionetti E, Catassi C. New clues in celiac disease epidemiology, pathogenesis, clinical manifestations, and treatment. Int Rev Immunol 2011;30:219-231.

5. Guandalini S, Setty M. Celiac disease. Curr Opin Gastroenterol 2008;24:707-712.

6. Hallert C, Grant C, Grehn S, et al. Evidence of poor vitamin status in coeliac patients on a gluten-free diet for 10 years. Aliment Pharmacol Ther 2002;16:13331339.

7. Halfdanarson TR, Litzow MR, Murray JA. Hematologic manifestations of celiac disease. Blood 2007;109:412421.

8. Friedman A. Micronutrient deficiencies in pediatric celiac diesase. ICAN: Infant, Child, Adolescent \& Nutrition 2012;4:156-167.

9. McCully KS. Homocysteine, vitamins, and vascular disease prevention. Am J Clin Nutr 2007;86:15631568.

10. Voutilainen S, Virtanen JK, Rissanen TH, et al. Serum folate and homocysteine and the incidence of acute coronary events: the kuopio Ischaemic heart disease risk factor study. Am J Clin Nutr 2004;80:317-323.

11. Wald DS, Law M, Morris JK. Homocysteine and cardiovascular disease: evidence on causality from a metaanalysis. BMJ 2002;325:1202.

12. Homocysteine studies collaboration. Homocysteine and risk of ischemic heart disease and stroke: a metaanalysis. JAMA 2002;288:2015-2022.

13. Den Heijer M, Lewington S, Clarke R. Homocysteine, MTHFR and risk of venous thrombosis: a metaanalysis of published epidemiological studies. J Thromb Haemost 2005;3:292-299.

14. Humphrey LL, Fu R, Rogers K, Freeman M, Helfand M. Homocysteine level and coronary heart disease incidence: a systematic review and metaanalysis.Mayo Clin Proc 2008;83:1203-1212.

15. Dickey W, Ward M, Whittle CR, et al. Homocysteine and related B-vitamin status in coeliac disease: effects of gluten exclusion and histological recovery. Scand $J$ Gastroenterol 2008;43:682-688.

16. Saibeni S, Lecchi A, Meucci G, et al. Prevalence of hyperhomocysteinemia in adult gluten-sensitive enteropathy at diagnosis: role of B12, folate, and genetics. Clin Gastroenterol Hepatol 2005;3:574-580.

17. Ferretti A, Parisi P, Villa MP. The role of hyperhomocysteinemia in neurological features associated with coeliac disease. Med Hypotheses 2013;81:524-531.

18. Malinow MR, Bostom AG, Krauss RM. Homocyst(e) ine, diet, and cardiovascular diseases: a statement for healthcare professionals from the Nutrition Committee, American Heart Association. Circulation 1999;99:178182.
19. Husby S, Koletzko S, Korponay-Szabó IR, et al. European society for pediatric gastroenterology, hepatology, and nutrition guidelines for the diagnosis of coeliac disease. J Pediatr Gastroenterol Nutr 2012;54:136-160.

20. Oberhuber G, Granditsch G, Vogelsang $H$. The histopathology of coeliac disease: time for a standardized report scheme for pathologists. Eur J Gastroenterol Hepatol 1999;11:1185-1194.

21. Shephard S, Gibson P. Nutritional inadequacies of the gluten-free diet in both recently-diagnosed and long term patients with coeliac disease. J Hum Nutr Diet 2013;26:349-358.

22. Kemppainen TA, Kosma VM, Janatuinen EK, Julkunen RJ, Pikkarainen PH, Uusitupa MI. Nutritional status of newly diagnosed celiac disease patients before and after the institution of a celiac disease diet-association with the grade of mucosal villous atrophy. Am J Clin Nutr 1998;67:482-487.

23. Valente FX, Campos Tdo N, Moraes LF, et al. B vitamins related to homocysteine metabolism in adults celiac disease patients: a cross-sectional study. Nutr J 2015;14:110.

24. Wierdsma NJ, van Bokhorst-de van der Schueren MA, Berkenpas M, Mulder CJ, van Bodegraven AA. Vitamin and mineral deficiencies are highly prevalent in newly diagnosed celiac disease patients. Nutrients 2013:5:3975-3992.

25. Balamtekin N, Uslu N, Baysoy G, et al. The presentation of celiac disease in 220 Turkish children. Turk J Pediatr 2010;52:239-244.

26. Kuloğlu Z, Kırsaçlığlu CT, Kansu A, Ensari A, Girgin N. Celiac disease: presentation of 109 children. Yonsei Med J 2009;50:627-623.

27. Sarı S, Dalgıç B. Çölyak hastalığı ön tanısı ile incelenen 227 hastanın değerlendirilmesi. Türkiye Klinikleri J Pediatr Sci 2005;1:38-40.

28. Isakov VA, Bogdanova AA, Bessonov VV et al. Effects of multivitamin, multimineral and phytonutrient supplementation on nutrient status and biomarkers of heart health risk in a russian population: a randomized, double blind, placebo controlled study. Nutrients 2018;10.

29. Overwiew of Homocysteine. Available at: https://www. uptodate.com/contents/overview-of-homocysteine?se arch=homocystein\&source=search_result\&selectedTitl $\mathrm{e}=1 \sim 150$ \&usage_type=default\&display_rank=1 Erişim Tarihi: 05 Mart 2018.

30. Hadithi M, Mulder CJ, Stam F, et al. Effect of B vitamin supplementation on plasma homocysteine levels in celiac disease. World J Gastroenterol 2009;15:955960. 
31. Boushey CJ, Beresford SA, Omenn GS, Motulsky AG. A quantitative assessment of plasma homocysteine as a risk factor for vascular disease probable benefits of increasing folic acid intakes. JAMA 1995;274:10491057.

32. Gentil-Kocher S, Bernard O, Brunelle F, et al. BuddChiari syndrome in children: report of 22 cases. J Pediatr 1988;113:30-38.

33. Grigg AP. Deep venous thrombosis as the presenting feature in a patient with coeliac disease and homocysteinaemia. Aust N Z J Med 1999;29:566-567.

34. Gefel D, Doncheva M, Ben-Valid E, el Wahab-Daraushe A, Lugassy G, Sela BA. Recurrent stroke in a young patient with celiac disease and hyperhomocysteinemia. Isr Med Assoc J 2002;4:222-223.

35. Gabrielli M, Santoliquido A, Gasbarrini G, Pola P, Gasbarrini A. Latent coeliac disease, hyperhomocysteinemia and pulmonary thromboembolism: a close link?. Thromb Haemost 2003;89:203-204.

36. Pitocco D, Zaccardi F, Martini F, et al. The cardiovascular relevance of celiac disease. Diabetes Care 2012;35:20.

37. De Marchi S, Chiarioni G, Prior M, Arosio E. Young adults with coeliac disease may be at increased risk of early atherosclerosis. Aliment Pharmacol Ther 2013;38:162-169 